\title{
"Organizational culture influenced by leadership styles: the case of private businesses in Kosovo"
}

\begin{tabular}{|c|c|}
\hline AUTHORS & $\begin{array}{l}\text { Alma Shehu Lokaj (D https://orcid.org/0000-0001-8719-0131 } \\
\text { R http://www.researcherid.com/rid/AAD-4409-2019 } \\
\text { Thelleza Latifi Sadrija (D https://orcid.org/0000-0003-0503-8203 } \\
\mathbb{R} \text { https://publons.com/researcher/ABA-2247-2020 }\end{array}$ \\
\hline ARTICLE INFO & $\begin{array}{l}\text { Alma Shehu Lokaj and Thelleza Latifi Sadrija (2020). Organizational culture } \\
\text { influenced by leadership styles: the case of private businesses in Kosovo. } \\
\text { Problems and Perspectives in Management, 18(3), 306-314. } \\
\text { doi:10.21511/ppm.18(3).2020.25 }\end{array}$ \\
\hline DOI & http://dx.doi.org/10.21511/ppm.18(3).2020.25 \\
\hline RELEASED ON & Wednesday, 30 September 2020 \\
\hline RECEIVED ON & Tuesday, 14 July 2020 \\
\hline ACCEPTED ON & Monday, 21 September 2020 \\
\hline LICENSE & $\begin{array}{l}(\mathrm{oc}) \mathrm{EY} \\
\text { This work is licensed under a Creative Commons Attribution } 4.0 \text { International } \\
\text { License }\end{array}$ \\
\hline JOURNAL & "Problems and Perspectives in Management" \\
\hline ISSN PRINT & $1727-7051$ \\
\hline ISSN ONLINE & $1810-5467$ \\
\hline PUBLISHER & LLC "Consulting Publishing Company "Business Perspectives" \\
\hline FOUNDER & LLC "Consulting Publishing Company "Business Perspectives" \\
\hline
\end{tabular}

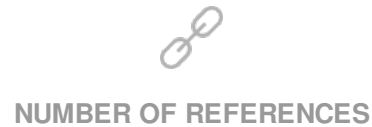

24
NUMBER OF FIGURES

0
ニニシ

NUMBER OF TABLES

7

(C) The author(s) 2021. This publication is an open access article. 


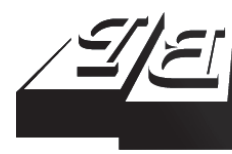

\section{BUSINESS PERSPECTIVES}

()

LLC "CPC "Business Perspectives" Hryhorii Skovoroda lane, 10, Sumy, 40022, Ukraine www.businessperspectives.org
Received on: $14^{\text {th }}$ of July, 2020 Accepted on: $21^{\text {st }}$ of September, 2020 Published on: $30^{\text {th }}$ of September, 2020

() Alma Shehu Lokaj, Thelleza Latifi Sadrija, 2020

Alma Shehu Lokaj, Dr., Ph.D., Teaching Assistant, Department of Business Administration, Faculty of Business, University "Haxhi Zeka", Peja, Kosovo. (Corresponding author)

Thelleza Latifi Sadrija, Dr., Ph.D. Teaching Assistant, Department of Management in Tourism, Faculty of Management of Tourism, Hospitality and Environment, University "Haxhi Zeka", Peja, Kosovo.

\section{ORGANIZATIONAL CULTURE INFLUENCED BY LEADERSHIP STYLES: THE CASE OF PRIVATE BUSINESSES IN KOSOVO}

\begin{abstract}
The characteristics and importance of leadership styles to organizational change are of particular importance for the development of organizational culture. This study aims to test leadership styles and the impact of the correlation between leadership style and organizational culture on the level of employees' readiness across a range of leadership outcome measures. This study provides empirical evidence for the impact of leadership styles on organizational culture and vice versa. A questionnaire was distributed to 450 employees in private organizations in Kosovo. The obtained results show that organizational culture was a significant predictor for both transactional and laissez-faire leadership styles. Based on the dimensions of organizational culture concerning Kosovar leadership styles (transformational, transactional, laissez-faire), their mutual influence dominates more on one variable and less on any other variable as a measuring mechanism for outputs and their interpretation. The study will help the organizations' leadership understand that their leading style influences the organizational culture and, as such, the employees' performance. In Kosovo, the concept of organizational culture concerning Kosovar leadership has not been properly developed, and measures should be taken by private businesses to settle this issue.
\end{abstract}

Keywords

leadership, organizations, influence, culture, performance, employees

JEL Classification L25, M12, O15

\section{INTRODUCTION}

Leadership and organizational culture are considered the two most important elements for businesses that claim success and gain a competitive advantage in the market.

Leadership and its influence play an important role in economic development, and Kosovo, as a country in transition, Kosovo is facing unprepared leadership and difficulties in finding a successful concrete business model. In Kosovo, very little or no research is devoted to culture and leadership styles and the connections that these together have in the business performance. Collaborative employee-leader relationships are seen as something abstract in Kosovo businesses, and they (employees) very often feel that they do not belong to the place where they work. Although there has been little change in recent years, this issue remains challenging for businesses that want to succeed in the market in which they operate. This paper aims to raise awareness of private business leaders in Kosovo on the importance of organizational culture, and in our case, influenced by leadership styles. The study aims to identify the relationships between leadership style and organizational culture in private businesses in Kosovo.

Referring to Kosovo's economic development, the way that leadership approaches employees, this paper focuses on the aspects of organiza- 
tional culture and its impact on leadership styles. Continuing with the analysis of which factor has the greatest impact on leadership styles, another problem addressed is employees' lack of information on organizational culture.

\section{LITERATURE REVIEW}

As leaders represent the most important business development factor, and their business activity depends on business success, leadership styles and leader influence are the most important elements for the organizations. Burns (1978) showed that leaders' role is to encourage the followers and give them the chance to change and be successful in the organization, motivate and create a sense of identity, a role model that inspires to takes greater ownership of followers' work. A transformational leader understands each follower's strengths and weaknesses and assigns a task that enhances each individual's performance (Burns, 1978).

By focusing on the three leadership styles and their function in private businesses, expectations will be important based on the role of each type of leadership as the transformer that drives the organization to success by profoundly influencing followers' beliefs about how to be an organization (Bass \& Avolio, 1994). Studies have shown that culture has a direct impact on leadership styles (Uma, 2010). Transactional leadership is that leader who uses the control and rewards mechanism to motivate his/her subordinates (Bass \& Avolio, 1994). Laissez-faire leaders are not accountable, not recipients of remembrances, do not use their power, and avoid involvement when important issues arise (Bass \& Riggio, 2006). According to the study of Liao et al. (2017), transactional leadership, with the relationship between the leaders and subordinates being based on reciprocity, is oriented toward benefit, with a focus on avoiding errors. Herrmann and Felfe (2014) claim that transformational leadership is supposed to improve employee creativity. The results showed that transformational leadership led to higher levels of creativity than transactional leadership. However, the results of the meta-analytic research of Jung (2001) on the relationship between transformational leadership and creativity are conflicting. In contrast to Jung (2001), the study of Liao et al. (2017) shows that transformational leadership, which is now receiving more attention, highlights the stimula- tion of staff members' spontaneous awareness and self-confidence to raise the morale and level of motivation. The results of Majd, Amarachi, and Shehu (2018) show that transformational leadership behaviors are associated with skills approach: technical, human, and conceptual skills; transactional leadership behaviors are related to skills approach: technical, human, and conceptual skills; and there is variance in transformational and transactional leadership behaviors, and skills approach at three levels of management. Cabrales, Barrachina, and Fernandez (2017) agree that leadership styles are crucial triggers for dynamic capabilities. It could be said that how top managers send messages will affect the policies and practices they implement to develop the capabilities they are interested in.

Many authors think that the laissez-faire style negatively influences organizational culture and performance, assuming that laissez-faire style exhibits frequent absence and lack of involvement during critical junctures (Eagly \& Schmidt, 2003). Tosunoglu and Ekmekci (2016) state that the laissez-faire style of leadership is one of the ineffective and destructive leadership styles, which is assumed to erode the trust both in supervisors and organizations.

According to Mas'ud (cited from Purnama 2013), organizational culture is a system of meanings, values, and beliefs held together in an organization, a reference to action and differentiates one organization from another organization. According to Hofstede (2008), "Culture is the collective programming of the mind that distinguishes the members of one group or category of people from others". Businesses need to choose the right style of leadership. According to Spears (1998), as cited by Aydin (2018), a leader's ability to communicate is crucial; however, very few receive attention. Tsai (2011) declares that organizational culture refers to the beliefs and values that have existed in an organization for a long time and the staff's beliefs and the foreseen value of their work that will influence their attitudes and behavior. According to Hofstede (2008), at the organizational level, cul- 
ture can be defined as the collective programming of the minds of group members with which one group differs from other groups in the same way as the definition of national cultures. However, he added that one organization is more or fewer complexes and less dispersed than unicorn (McSweeney, 2002).

In another definition given by Schein (1992, p. 12), organizational culture is "Culture is a pattern of shared tacit assumptions that was learned by a group as it solved its problems of external adaptation and internal integration, that has worked well enough to be considered valid and, therefore, to be taught to new members as the correct way to perceive, think, and feel in relation to those problems."

Organizational outcomes are influenced by leadership (Hoewell \& Avolio, 1993; Bycio, Hackett, \& Allen, 1955), and these outcomes depend on organizational culture (Peters \& Waterman, 1982; Denison, 1990; Kotter \& Heskett, 1992), while even stronger claims revolve around the conclusion that organizational culture and leadership are related to each other, and both are important in determining the success of an organization (Roper, 1997). The importance of the culture within the organizations determines the behavior of management and employees and is a key that plays an important role relating to economic behavior (Widiana \& Harsanto, 2017)

Many studies have been done to study the effects of leadership styles and organizational culture, and none has been done in our country to evaluate and take measures to improve the business performance and increase employees' motivation through the right leadership actions. Considering this fact, it is important to study the relationship between the leadership style and organizational culture in our country and help those businesses included in this study.

\section{AIMS}

The paper aims to identify the correlation between leadership styles and organizational culture in private businesses in Kosovo. Based on the evaluation of leadership styles (transformational, transactional style, and laissez-faire), the participants of this study have the opinion that in private busi- nesses in Kosovo, the most prevalent leadership style is the transactional style. For the evaluation of organizational culture, the authors have obtained the results from the participants' opinion that organizational culture is not a widely known factor by employees in the private sector. Training and other methods to address the problems will improve leaders' behavior and achieve businesses' objectives.

\section{RESEARCH METHODOLOGY AND HYPOTHESES}

This paper is based on the methods used to perform an evaluative analysis of the correlation between variables (organizational culture dimension correlations, correlation analysis for leadership styles and organizational culture, multiple regression model summarizations for leadership style). Comparison of quantitative data obtained from various statistical analysis reports with qualitative empirical study data was provided through questionnaires distributed to private businesses in Kosovo. Data processing was done through the STATA program. From 450 questionnaires, 427 were received from the employees of different private organizations of the study. All the questions included were answered using the 5 points of the Likert scale of strongly disagree, disagree, uncertain, agree, and strongly agree. This study's findings are valid for Kosovar organizational culture but may be applied to other cultures of transition countries.

The research hypotheses are as follows:

H1: There is a positive relationship between leadership styles.

H2: Organizational culture is an important predictor of leadership styles in Kosovo businesses.

Research question 1: Is there a positive relationship between leadership style and organizational culture?

Research question 2: Does organizational change affect the relationship between leadership style and organizational culture? 
Research question 3: Is the organizational culture an important predictor for leadership style in Kosovar businesses?

\section{RESULTS}

The questionnaire was completed by the following groups of respondents: 1) employees, 2) administration, 3) second-level manager, 4) top manager (some have been the owners of the organizations). The survey was conducted in private businesses considering the pre-selection, which also represented the local economic worker. $40.7 \%(N=$ 174) of the participants in the survey are male and $59.3 \%(N=253)$ female. The average age is 32.5 years $(S D=8.7)$. The minimum age is 18 years, and the maximum 62 years.

Table 1 shows that $11.9 \%$ reported poor laissez-faire style and $15.7 \%$ poor transformational style.

Participants also gave an opinion on organizational culture. Table 1 shows that $21.1 \%$ of the participants rated organizational culture as progressive in their enterprises, while $10.3 \%$ were not progressive and $16.9 \%$ as slightly progressive. The results show that organizational culture can be a factor little known by private-sector employees.

Organizational culture was found to be weakly and positively correlated with transactional style $(r=.399, p<.001)$ and laissez-faire style $(r=.364$, $p<.001)$. This result may reflect that many organizations have a more mixed style than just one leadership style. This study confirms the first hypothesis that there is a relationship between leadership styles and organizational culture (Table 2). In the first model of linear regression (Table 3), the transformational style of leadership is placed with organizational culture. The strength of the correlation is average. Regression analysis has shown that $22.9 \%$ of the transformational leadership style variance is explained by organizational culture $(R=.479, \boldsymbol{\beta}(.16, .23)=.19, p=<.001)$.

Table 3. Summary of the model $\left(Y=B_{0}+B_{1} X_{1}\right)$

Source: Authors.

\begin{tabular}{c|c|c|c|c}
\hline Model 1 & $\mathbf{R}$ & $\boldsymbol{R}$-squared & $\begin{array}{c}\text { Adjusted } \\
\boldsymbol{R} \text {-squared }\end{array}$ & $\begin{array}{c}\text { Std. error of } \\
\text { the estimate }\end{array}$ \\
\hline 1 & $.479^{a}$ & .229 & .227 & 3.32 \\
\hline
\end{tabular}

Note: a. Predictors: (constant), organizational culture (2).

The regression equation was found to be statistically significant $(F(1,426)=80.25, p<.001)$ with

Table 1. Percentage descriptive data for leadership styles rated according to participants' opinion

\begin{tabular}{|c|c|c|c|c|}
\hline Percentiles & Organizational culture & Transformational style & Transactional style & Laissez-faire style \\
\hline Percentile 10 & $10.3 \%$ & $15.7 \%$ & $6.8 \%$ & $11.9 \%$ \\
\hline Percentile 25 & $16.9 \%$ & $14.5 \%$ & $20.1 \%$ & $17.1 \%$ \\
\hline Percentile 50 & $26.7 \%$ & $22.2 \%$ & $26.0 \%$ & $33.3 \%$ \\
\hline Percentile 75 & $25.1 \%$ & $32.3 \%$ & $23.9 \%$ & $18.0 \%$ \\
\hline Percentile 95 & $16.9 \%$ & $10.3 \%$ & $23.2 \%$ & $15.0 \%$ \\
\hline Percentile 99 & $4.2 \%$ & $4.9 \%$ & $6.8 \%$ & $4.7 \%$ \\
\hline
\end{tabular}

Table 2. Correlation data between organizational culture and leadership styles

Source: Authors.

\begin{tabular}{|c|c|c|c|c|}
\hline \multicolumn{2}{|c|}{ Leadership styles } & \multirow{2}{*}{$\frac{\text { Organizational culture }}{479^{* *}}$} & \multirow[t]{2}{*}{ Transformational style } & \multirow[t]{2}{*}{ Transactional style } \\
\hline \multirow{3}{*}{ Transformational style } & $R$ & & & \\
\hline & $P$ & .000 & & \\
\hline & N & 427 & & \\
\hline \multirow{3}{*}{ Transactional style } & $\mathrm{R}$ & $.399^{* *}$ & $.780^{* *}$ & \\
\hline & $P$ & .000 & .000 & \\
\hline & N & 427 & 427 & \\
\hline \multirow{3}{*}{ Laissez-faire style } & $R$ & $364^{* *}$ & $670^{* *}$ & $609^{* *}$ \\
\hline & $P$ & .000 & .000 & .000 \\
\hline & $\mathrm{N}$ & 427 & 427 & 427 \\
\hline
\end{tabular}

Note: $R$ - correlation coefficient, $P$ - significance coefficient, $N$-number. 
Table 4. Summary regression model for transactional and laissez-faire leadership styles.

Source: Authors

\begin{tabular}{c|c|c|c|c}
\hline Model & $\mathbf{R}$ & $R$-squared & Adjusted $R$-squared & Std. error of the estimate \\
\hline 1 & $.399^{\mathrm{a}}$ & .159 & .157 & 3.103 \\
\hline 2 & .364 & .133 & .131 & 2.945 \\
\hline
\end{tabular}

Note: a. Predictors: (Constant), organizational culture, b. Dependent variable: transactional style (model 1), c. Dependent variable: laissez-faire style (model 2 ).

Table 5. Summary of the multiple regression model for transformational style with components of organizational culture

Source: Authors.

\begin{tabular}{|c|c|c|c|c|c|}
\hline Model & $\mathbf{R}$ & $R$-squared & Adjusted $R$-squared & Std. error of the estimate & Durbin-Watson \\
\hline Team orientation & $.464^{\mathrm{a}}$ & .215 & .213 & 3.35670 & \\
\hline Empowerment & $.528^{b}$ & .279 & .276 & 3.22030 & \\
\hline Creating change & $.565^{c}$ & .319 & .314 & 3.13301 & \\
\hline Organizational learning & $.580^{d}$ & .336 & .330 & 3.09747 & \\
\hline Stability & $.589^{e}$ & .347 & .340 & 3.07519 & \\
\hline Strategic direction & $.598^{f}$ & .358 & .348 & 3.05424 & \\
\hline Involvement & $.605^{\mathrm{g}}$ & .366 & .355 & 3.03841 & .332 \\
\hline
\end{tabular}

Note: Dependent variable: transformational style.

a value of $R^{2}=.157$. This equation was also statistically significant for laissez-faire style $(F(1$, $426)=65.09, p<.001)$ with a value of $R^{2}=.133$. The results show that organizational culture was found to be significant predictor for both transactional style $(R=.399, \beta(.16, .23)=.19, p=<.001)$, and laissez-faire $(R=.364, \beta(.16, .23)=.19, p=<.001)$. The results show that organizational culture predicts $15.7 \%$ of the transactional style variance and $13.3 \%$ of the laissez-faire style of leadership. Based on the result of the summary regression model, it is found that organizational culture is an important predictor of leadership styles.

A prediction equation was constructed through multiple regression analysis following the stepwise method to determine the impact of organization- al culture components as predictors of leadership styles. This analysis has shown that for the transformational leadership style, only seven components of organizational culture, such as team orientation, are included in the model; strengthening; creating change; organizational learning; stability; strategic direction; involvement. Meanwhile, the other components have not been statistically significant for the transformational leadership style. As shown in Table 5, these factors explain $36.6 \%$ of the variance of transformational leadership, implying that other factors moderate the transformational style.

Table 6 shows that for transactional leadership style, multiple regression analysis using the stepwise model only included eight components of organizational culture such as team orientation,

Table 6. Summary of multiple regression model for transactional style with components of organizational culture

Source: Authors.

\begin{tabular}{|c|c|c|c|c|c|}
\hline Model & $\mathbf{R}$ & $R$-squared & Adjusted $R$-squared & Std. error of the estimate & Durbin-Watson \\
\hline Team orientation & $.393^{\mathrm{a}}$ & .154 & .152 & 3.11182 & \\
\hline Suitability & $.464^{\mathrm{b}}$ & .216 & .212 & 3.00004 & \\
\hline Creating change & $.487^{\circ}$ & .237 & .232 & 2.96138 & \\
\hline Strategic direction & $.508^{d}$ & .258 & .251 & 2.92391 & \\
\hline Empowerment & $.529^{\mathrm{e}}$ & .280 & .271 & 2.88468 & \\
\hline Stability & $.544^{f}$ & .296 & .286 & 2.85634 & \\
\hline Organizational learning & $.559^{g}$ & .313 & .301 & 2.82532 & \\
\hline Consumer focus & $.572^{\mathrm{h}}$ & .328 & .315 & 2.79743 & .376 \\
\hline
\end{tabular}

Note: Dependent variable: transformational style. 
Table 7. Summary of the multiple regression model for laissez-faire style with components of organizational culture

Source: Authors.

\begin{tabular}{|c|c|c|c|c|c|}
\hline Model & $\mathbf{R}$ & $R$-squared & Adjusted $R$-squared & Std. error of the estimate & Durbin-Watson \\
\hline Empowerment & $.474^{a}$ & .225 & .223 & 2.78567 & \\
\hline Mission & $.516^{\mathrm{b}}$ & .266 & .263 & 2.71336 & \\
\hline Coordination/integration & $.546^{c}$ & .298 & .293 & 2.65721 & \\
\hline Team orientation & $.568^{d}$ & .323 & .317 & 2.61203 & \\
\hline Aims and objectives & $.591^{e}$ & .349 & .341 & 2.56468 & \\
\hline Organizational learning & $.614^{f}$ & .377 & .368 & 2.51184 & \\
\hline Involvement & $.646^{g}$ & .417 & .408 & 2.43172 & \\
\hline Agreement & $.651^{\mathrm{h}}$ & .424 & .413 & 2.42079 & \\
\hline Suitability & $.656^{i}$ & .430 & .418 & 2.41097 & .324 \\
\hline
\end{tabular}

Note: Dependent variable: laissez-faire style.

adaptability, creating change; strategic direction; empowerment; stability; organizational learning; and consumer focus. Meanwhile, the other components have not been statistically significant for the transformational leadership style. As shown in Table 7 , these factors account for $32.8 \%$ of the transactional leadership variance, implying that other factors moderate the transactional style.

According to the stepwise model, the multiple regression analysis excludes factors that are not statistically significant; laissez-faire style is the dependent variable and all components of organizational culture as predictors (independent variables).

Table 7 shows that for laissez-faire leadership style, the multiple regression analysis according to stepwise model includes only nine components of organizational culture such as empowerment, mission, coordination/integration; team orientation, aims and objectives, organizational learning; involvement, agreement, and adaptability.

Meanwhile, the other components have not been statistically significant for the laissez-faire style of leadership. As shown in Table 7, these factors explain $43 \%$ of the variance of transformational leadership, implying that other factors moderate the laissez-faire style.

\section{DISCUSSION}

The organizational culture is very important not only for the organizations but also for the employees. From the results of this study, one can see that a high percentage of the employees rate their or- ganization, not in progress, and this should be an issue to be improved in the organizations surveyed.

The Kosovo leadership's main aspects lie in the fact that there are contradictions, inconsistencies, and all cultural aspects within the company are held by the owners their privilege. Simultaneously, according to international best practice and elaborations in the theoretical overview of this paper, it is recommended that senior management, owners, and shareholders decentralize competencies to middle and lower management levels according to the respective position.

Motivation is a very important approach in increasing organizational performance; it is recommended using more motivational methods from leadership in private businesses, which should motivate employees to look at problems from a new perspective and contribute to increasing their potential. The leaders in private businesses must tend to motivation and an individualized analysis of employees. These results were obtained from the stepwise model in the multiple regression analysis for the laissez-faire style as a dependent variable and all organizational culture components as predictors: team orientation, empowerment, mission, coordination/integration, goals and objectives, organizational learning, inclusion, agreement, and adaptability. All these factors explain $43 \%$ of the laissez fair leadership variance, letting us understand that other factors moderate laissez-faire style.

According to the data and the obtained results, the job position had a statistically significant effect on the transformational and transactional style and not on the laissez-faire. 
According to the results based on the third question "What are the factors influencing leadership styles in private enterprises in Kosovo?", there are gender dif- ferences in reporting opinions on leadership styles. There are differences in reporting opinions on leadership styles among employees and managerial staff.

\section{CONCLUSION}

Based on the evaluation of Kosovar leadership styles (transformational, transactional, and laissez-faire style), the participants of this study believe that in Kosovo's private businesses, the most prevalent leadership style transactional style. This leadership style motivates and rewards externally. The organizational culture results show that this is a very little known factor by the employees and a very well-known factor for the management of these businesses.

The results for the first hypothesis "There is a positive relationship between leadership style and organizational culture", by analyzing the components such: stimulation, responsibilities, and motivation, show that leadership styles stimulate the employees to see the problems in a new point of view and contribute to enhancing their potentials.

Based on the results regarding the testing of the impact of organizational culture dimensions on the total organizational culture, organizational systems promote an efficient structure; the highest correlation values are obtained in skills development. The organization constantly invests in developing skills employees to maintain competitiveness and meet the business's ongoing needs. According to the results obtained, the higher the reporting points in the dimensions of organizational culture, the more progressive the organizational culture in Kosovo's private businesses.

A positive correlation was also found in the statistical aspect between the customer focus, organizational learning, mission, strategic direction, goals, and objectives with the organizational culture.

The first research question results: "Is there a positive relationship between leadership styles and organizational cultures?" show that there is a strong correlation between transformational style and organizational culture and organizational culture has a weak correlation and positive with transactional and laissez-faire styles. This result may reflect the fact that private businesses in Kosovo use a mixed style of leadership. The analyses confirm the first hypothesis that there is a positive relationship between leadership style and organizational culture.

The regression analysis has shown that $22.9 \%$ of transformational leadership style variance is explained by organizational culture and that organizational culture is an important predictor of both transactional and laissez-faire style, i.e., organizational culture predicts $15.7 \%$ of the transactional style variance and $13.3 \%$ of the laissez-faire style.

In the transformational leadership style analyses, only seven components of organizational culture are included in the model (stepwise model) such as team orientation, empowerment, change-making, organizational learning, sustainability, strategic direction, and inclusion and explain $36.6 \%$ of transformational leadership variance, letting us understand that other factors moderate this style.

For the transactional leadership style, the multiple regression analysis according to the stepwise model included only eight components of organizational culture, such as team orientation, adaptability, change-making, strategic direction, empowerment, sustainability, organizational learning, and consumer focus. These factors explain $32.8 \%$ of the transactional leadership variance, letting us understand that other factors moderate this style. 


\section{AUTHOR CONTRIBUTIONS}

Conceptualization: Alma Shehu Lokaj, Thelleza Latifi Sadrija.

Formal analysis: Alma Shehu Lokaj, Thelleza Latifi Sadrija.

Investigation: Thelleza Latifi Sadrija.

Methodology: Alma Shehu Lokaj, Thelleza Latifi Sadrija.

Resources: Alma Shehu Lokaj.

Supervision: Alma Shehu Lokaj.

Writing - original draft: Thelleza Latifi Sadrija.

\section{REFERENCES}

1. Bass, B. M., \& Avolio, B. J. (1994). Improving organizational effectiveness through transformational leadership. Thousand Oaks, CA: Sage Publications.

2. Bass, B. M., \& Riggio, R. E. (2006). Transformational Leadership, Erlbaum, Mahwah.

3. Burns, J. M. (1978). Leadership. New York. Harper \& Row.

4. Bycio, P., Hackett, R. D., \& Allen, J. S. (1995). Further assessments of Bass's (1985) conceptualization of transactional and transformational leadership. Journal of Applied Psychology, 80, 468-478. https://doi.org/10.1037/00219010.80.4.468

5. Deal, T. E., \& Kennedy, A. A. (1982). Corporate Cultures. Reading MA, Addison-Wesley.

6. Denison, D. R. (1990). Corporate culture and organizational effectiveness. New York: John Wiley \& Sons.

7. Eagli, A. H., Johannesen-Schmidt, M. C., \& Van Engen, M. L. (2003). Transformational, Transactional, and Laissez-Faire Leadership Styles: A Meta-Analysis Comparing Women and Men. Psychological Bulletin, 129(4), 569-591. https://doi.org/10.1037/00332909.129.4.569

8. Herrmann, D., \& Felfe, J. (2014). Effects of leadership style, creativity technique and personal initiative on employee creativity. British Journal of Management, 25(2), 209-227. https://doi.org/10.1111/ j.1467-8551.2012.00849.x
9. Hofstede, G. (2008). Value Survey Module 2008 manual. IRIC, University of Tilburg, Maastricht, The Netherlands.

10. Howell, J. M., \& Avolio, B. J. (1993). Transformational leadership, transactional leadership, locus of control and support for innovation: Key predictors of consolidated-business unit performance. Journal of Applied Psychology, 78, 891-902. https://doi. org/10.1037/0021-9010.78.6.891

11. Jung, D. I. (2001). Transformational and transactional leadership and their effects on creativity in groups. Creativity Research Journal, 13(2), 185-195. Retrieved from https://www.researchgate.net/ publication/247807610_Transformational_and_Transactional_Leadership_and_Their_Effects_ on_Creativity_in_Groups

12. Kotter, J. P., \& Heskett, J. L. (1992). Corporate Culture and Performance. New York: Free Press.

13. Liao, S.-H., Chen, C.-C., Hu, D.-C., Chung, Y.-C., \& Liu, C.-L. (2017). Assessing the influence of leadership style, organizational learning and organizational innovation. Leadership \& Organization Development Journal, 38(5), 590-609. https://doi. org/10.1108/LODJ-11-2015-0261

14. Lopez-Cabrales, A., BornayBarrachina, M., \& Diaz-Fernandez, M. (2017). Leadership and dynamic capabilities: the role of HR systems. Personnel Review, 46(2), 255-276. https://doi.org/10.1108/ PR-05-2015-0146
15. McSweeney, B. (2002). Hofstede's Model of National Cultural Differences and Their Consequences: A Triumph of Faith - a Failure of Analysis. Human Relations, 55(1), 89-118. https://doi. org/10.1177/0018726702551004

16. Megheirkouni, M., Amaugo, A., \& Jallo, S. (2018). Transformational and transactional leadership and skills approach: Insights on stadium management. International Journal of Public Leadership, 14(4), 245-259. https://doi.org/10.1108/ IJPL-06-2018-0029

17. Peters, T. J., \& Waterman, R. H. (1982). In Search of Excellence: Lessons from America's Best-Run Companies. New York: Harper \& Row.

18. Purnama, Chamdan. (2013). Influence Analysis of Organizational Culture Organizational Commitment Job and Satisfaction Organizational Citizenship Behavior (OCB) Toward Improved Organizational Performance. International Journal of Business, Humanities and Technology, 3(5), 86-100. Retrieved from https:// www.semanticscholar.org/paper/ Influence-Analysis-of-Organizational-Culture-Job-Purnama-Ting gi/6fbef373549dcf06af274536d4f9 e2f0c018f289

19. Roper, S. (1997). Strategic initiatives and small business performance: an exploratory analysis of Irish companies. Entrepreneurship and Regional Development, 9(4), 353-364. https://doi. org/10.1080/08985629700000020 
20. Schein, E. H. (1992). The Corporate Culture Survival Guide.

21. Shu-Hsien Liao, Chih-Chiang Chen, Da-Chian Hu, Yu-Chun Chung, \& Chiu-Ling Liu. (2017). Assessing the influence of leadership style, organizational learning and organizational innovation. Leadership \& Organization Development Journal, 38(5), 590-609.
https://doi.org/10.1108/LODJ-112015-0261

22. Tsai Yafang. (2011). Relationship between Organizational Culture, Leadership Behavior and Job Satisfaction. BMC Health Service Research, 11, 1-9. https://doi. org/10.1186/1472-6963-11-98

23. Uma D. Jogulu. (2010). Culturally - linked leadership styles. Leader- ship \& Organization Development Journal, 31(8), 709-719. Retrieved from https://pdfs.semanticscholar. org/183b/6fa870b0678e438cd8ele d2da18f528f9480.pdf

24. Widiana, S., \& Harsanto, B. (2017). The impact of transformational leadership and organization culture. In Palgrave Handbook of Leadership in Transforming Asia (pp. 503-517). 